\title{
Women's History, Gender History and Debating Dichotomies
}

\author{
Franca Iacovetta \& Linda Kealey
}

Joan Sangster's "Beyond Dichotomies" (left history, 3.1, Spring/Summer 1995) is a polemic on the relationship between women's history and gender history. As such, it tends to bring out issues and highlight debates but, at the same time, it sometimes inevitably simplifies and potentially misrepresents in order to address important points. As friends and colleagues, we would like to take issue with some of the assertions and suggestions made in Sangster's piece. We think it is important to debate these issues and we hope to make a contribution. Such issues are central in feminist historical debates internationally and, while individuals who write Canadian women's history and gender history have clearly borrowed from the international literature, there has been no sustained Canadian "debate," at least not in print.

\section{Dichotomies}

Any Canadian debate will involve an ongoing discussion of the relevant literature produced in this country. Does the Canadian scene mirror precisely the international historiography and debate? Does the distinction drawn between women's historian/gender historian - a distinction Sangster has borrowed from the interna- 
tional debate - accurately reflect the Canadian context? Given the tiny body of work as yet available on gender history in Canada, we caution against drawing hard and fast conclusions or rigid boundaries. But we also suggest some alternative readings of the Canadian context.

We agree with Sangster that women's history and gender history approaches differ in some important respects (see below), but we suggest that her treatment of the Canadian historiography creates false dichotomies. The pigeon-holes of women's history/gender history ignore the fact that many feminist historians in Canada, including those cited by Sangster, have been working simultaneously in both areas, or that they have shifted between these and possibly other approaches. A few examples: Joy Parr, recognized as a leading practitioner of gender history, has followed her prizewinning Gender of Breadwinners with a new collection of essays on Ontario women's history which draws together a variety of perspectives and approaches. ${ }^{1}$ The works of socialist feminist scholars such as Bettina Bradbury, Lynne Marks and Ruth Frager have straddled various topics and approaches, including the labour histories of women workers and men workers, family and community history, and gender relations. ${ }^{2}$ Such fluidity helps explain

1 Joy Parr, The Gender of Breadwinners: Women, Men and Change in Two Industrial Towns, 1880-1950 (Toronto 1990); Parr, ed., A Diversity of Women: Ontario, 1945-1980 (Toronto 1995).

2 Bettina Bradbury, Working Families: Age, Gender and Daily Survival in Industrializing Montreal (Toronto 1993); see also her "Gender at Work at Home: Family Decisions, the Labour Market and Girls' Contributions to the Family Economy," in G. Kealey and G. Patmore, eds., Canadian and Australian Labour History: Towards a Comparative Perspective (St. John's 1990). Lynne Marks, Revivals and Roller Rinks: Religion, Leisure and Identity in Late 19th Century Small Town Ontario (Toronto 1996); see also her "The 'Halleujah Lasses': Working-class Women in the Salvation Army in English Canada, 1882-92," in Franca Iacovetta and Mariana Valverde, eds., Gender Conflicts: New Essays in Women's History (Toronto 1992), 67-117. Ruth Frager, Sweatshop Strife: Class, Ethnicity and Gender in the Jewish Labour Movement of Toronto, 1900-39 (Toronto 1992); see also her "Class, Ethnicity, and Gender in the Eaton Strikes of 1912 and 1934," in Iacovetta and Valverde, eds., Gender Conflicts, 189-228. 
apparent contradictions in Sangster's categorizations: why, for example, Karen Dubinsky ${ }^{3}$ is profiled first as a gender historian(109-11) and later, praised as a women's historian and specialist on violence against women.(120) While we agree with Sangster that new approaches can sometimes draw overly enthusiastic advocates, we suggest that the notion that there is a "story" that all of Canada's gender historians tell about the Whiggish ascent from women's to gender history distorts rather than illuminates the Canadian scene.

Sangster is correct to insist that we recognize the continuities between women's and gender history, the political engagement that many women's historians, including socialist feminists, had with their scholarship, and that women's history has always been about more than the recovery of the subject, "woman." Our disagreement is with Sangster's assertion that our colleagues working in the areas of gender relations and gendered identities have missed these linkages and continuities, or that they have eschewed any intellectual and political debts to women's history. Recent works in working-class history by Suzanne Morton, Mark Rosenfeld, and Nancy Forestell, for example, are gendered histories that are simultaneously firmly rooted in women's and feminist labour history. ${ }^{4}$

3 Karen Dubinsky, Improper Advances: Rape and Heterosexual Conflict in Ontario, 1890-1929 (Chicago 1993); see also "Introduction" to Iacovetta and Valverde, Gender Conflicts and her essay in that volume: "Maidenly Girls' or 'Designing Women'? The Crime of Seduction in Turn-of-the-Century Ontario," 27-66.

4 Suzanne Morton, Ideal Surroundings, Domestic Life in a Working-Class Suburb in the 1920s (Toronto 1995); see also, Janet Guildford and Suzanne Morton, eds., Separate Spheres: Women's Worlds in the 19th-Century Maritimes (Fredericton 1994). Mark Rosenfeld, "'It Was a Hard Life': Class and Gender in the Work and Family Rhythms of a Railway Town, 1920-1950," Historical Papers, CHA, 1988; Nancy Forestell, "All That Glitters is Not Gold: The Gendered Dimensions of Work, Family and Community Life in the Northern Ontario Goldmining Town of Timmins, 1909-1950," Ph.D thesis, University of Toronto, 1993. Her previous work focused on women's work in St. John's, Newfoundland; see "“Times Were Hard': the Pattern of Women's Paid Labour in St. John's Between the Two World Wars," Labour/Le Travail, 24 (Fall 1989), 147-66. 
The socialist feminist collective that wrote the introduction to Gender Conflicts reached similar conclusions to Sangster, arguing that women's history was about more than the study of women, that it has developed analytical tools for the study of related phenomena such as masculinity and gender relations, and that it is crucial that studies in gender history maintain a politically feminist, intellectually rigorous research agenda. Like Sangster, Dubinsky et. al. agreed with European historian, Gisela Bock, who argues in favour of a continuing relationship between women's and gender history. ${ }^{5}$ The editors of a forthcoming book on gender history in Canada concur. "We do not believe," write Cecilia Morgan, Kate McPherson and Nancy Forestell, "that an essential and fixed distinction exists between women's history and gender history ... we are struck by the links between the two areas; their relationship has often appeared much more symbiotic to us than the fundamental oppositions posited by some feminist historians.",

We therefore offer an alternative reading of the relevant Canadian scholarship produced thus far, namely that feminist insights critical to women's history have directly informed much of the work on the history of gender relations and gender identities. ${ }^{7}$ This does not mean, of course, that the shape of the field cannot change or that gender histories uninformed by feminist insights will not be written. It is precisely because of this possibility that we stress the importance of ensuring that feminist and socialist feminist perspectives and contributions continue to inform gender studies in Canada, whether practiced by male or female historians. Those of us who supervise graduate students taking up gender questions (predominantly women, but also some men) are in a critically strategic position in this regard. We need to encourage work rooted in

5 Gender Conflicts, xix-xx.

6 Cecilia Morgan, Kathryn McPherson and Nancy Forestell, eds., Gender in Canada: Essays on Masculinity and Femininity (forthcoming).

7 For a similar characterization, see Gail Cuthbert Brandt, "Broaching the Solitudes: Gender History in Theory and Practice in Canada," paper presented at the 18th International Congress of the Historical Sciences, Montreal (ICHS), August 28-30, 1995. 
feminist-inspired scholarship, not tell them they are making bad choices.

Sangster is, of course, correct to observe that there are several features that in recent years have come to distinguish gender history from women's history. Discussions about the relative merits of these differences have been central to the international debate. If, for example, women's historians foregrounded women's experiences and sought to identify the roots of oppression, gender historians were equally insistent that gender was a structural feature of historical events and institutions even when women were absent from them. Gender history has come to be associated with certain post-structuralist, Foucauldian and feminist theoretical insights regarding the decentred nature of power and its embodiment in multiple sites and relations, and it has pointed to the fractured and multi-layered character of identities. Not all the insights that have come to be associated with post-structuralism are necessarily entirely new to us as historians, for our very craft requires us to grapple with epistemological questions about how we read texts, "know" the past, and tell it to others. But it has compelled some historians to revisit such questions. ${ }^{8}$

Are all women's historians and gender historians cut from the same cloth? There seems to be an assumption that each group is monolithic, following the research agendas and theories that belong to each respective camp. In our reading, this assumption is not borne out by works in the field. Such an assumption implies that Canadian women's history, especially that which predates discus-

8 Morgan, McPherson and Forestell, "Introduction"; Parr, "Gender History and Historical Practice," Canadian Historical Review, 76, 3 (Sept. 1995), 354-76; Valerie Burton, "The Historical Paradox of Jack Tar: Male Identities and the Working Class in Canada and Britain Since 1870," paper presented to the 18th International Congress of the Historical Sciences, Montreal (August 1995). On the international discussion see, for example, the Spring 1993 issue of the Journal of Women's History with contributions by Sonya Rose, Kathleen Canning, Mariana Valverde and Anna Clark, among others. Much of this debate was prefigured in the debates about historical relativism in the 1930s; see Peter Novick, That Noble Dream: The "Objectivity Question" and the American Historical Profession (New York 1988). 
sions of gender history, fits into a mould. Such a perspective denies or at least downplays the differences and political debates that have occurred over the years. There have been and remain theoretical differences among historians researching women; there are also varying views of how that history should be written, what methods are most appropriate, and how much theory should be applied. Disagreement has been visible in a number of areas, for example, in how historians portray the suffrage movement and the "first wave" feminists. Socialist feminist historians, for example, have been taken to task for presenting women like Nellie McClung in too harsh a light by overemphasizing the limits of middle-class reform agendas and conservative notions of women's roles. Others would prefer to emphasize the "radical" nature of suffrage and reform women's demands, suggesting that women like McClung took substantial risks in advocating the vote for women. And, most recently, women of colour in particular have interrogated the racial assumptions based in imperial thought exhibited in the writings of first wave feminism. ${ }^{9}$

Likewise, there is a danger in portraying gender historians as monolithic. Are they all post-structuralists utilizing deconstruction as their weapon of choice? We are not convinced of this. Even the small body of Canadian gender history produced thus far defies this

9 For a revisionist perspective on first wave feminists, see Veronica Strong-Boag, "The Challenge of Fairness: Thinking About Canada's Two Feminist Waves," paper presented to the Colloque "Feminismes et cultures politiques nationales," Septieme entretiens du Centre Jacques Cartier, Rhône-Alpes 29 Nov-Dec 1994, Lyons, France; while self-critical, Strong-Boag's piece rewrites the historiography in such a way as to ignore the class-based critiques of the earlier literature. See also the critique of Carol Bacchi's 1983 book, Liberation Deferred?: The Ideas of the English Canadian Suffragists, 1877-1918 (Toronto 1983) by Ernie Forbes in "Battles in Another War: Edith Archibald and the Halifax Feminist Movement," and in "The Ideas of Carol Bacchi and the Suffragists of Halifax," in Forbes, Challenging the Regional Stereotype: Essays on the 20th Century Maritimes (Fredericton 1989). For a re-reading of Nellie McClung which raises questions of race and imperialism in her writings, see Arun P. Mukherjee, "In a Class of Her Own," Literary Review of Canada, July-August 1995 (a review of two new books on McClung). 
categorization, for historians writing about gender have approached the matter in different ways. Some historians have written about gender relations within a feminist and materialist framework: studies of working-class, immigrant men by Frager and Iacovetta, for example, offer no bold declarations about the greater theoretical sophistication of gender over women's history, and their analyses are clearly derived from women's history and feminist labour history as well as from immigration history. Patriarchy is not jettisoned. ${ }^{10}$ Other Canadian historians working in the area of gender history, to varying degrees and in various ways, have indeed borrowed from post-structuralist insights about power and identity, and they have taken up the challenge of textuality and representation posed by theories regarding the literary or linguistic production of meaning. (Some historians writing women's history have also found such insights useful, of course). But the question remains: have historians interested in "gender"denied the material basis of women's oppression? Have writers like Morgan, Lykke de la Cour or Mariana Valverde denied class, patriarchy or race/ethnicity as crucial categories, along with gender? ${ }^{11}$ Lynne Marks tells us that her research on the leisure and religious lives of middleclass and working-class women and men in small Ontario communities convinced her that age and marital status, as well as gender and class, mattered. Does this observation mean she abandoned feminist or socialist feminist questions? Or, rather, was she a historian paying attention to her evidence ${ }^{12}$ These are but a few examples that strike us as symptomatic of the problem of pigeon-

10 Judith Bennett used this phrase in "Feminism and History," Gender and History, 1, 3 (Autumn 1989).

11 See Morgan, McPherson and Forestell, Gender in Canada; Lykke de la Cour, Cecilia Morgan and Mariana Valerde, "Gender Regulation and State Formation in Nineteenth Century Canada," in A. Greer and I. Radforth, eds., Colonial Leviathan: State Formation in Mid-Nineteenth-Century Canada (Toronto 1992); Mariana Valverde, The Age of Light, Soap and Water: Moral Reform in English Canada, 1885-1925 (Toronto 1991).

12 See footnote 2 above for citations. 
holing authors; we invite other readers to consider these studies and decide for themselves.

\section{Labels and Fields}

Thus, while trying to untangle the question of dichotomies, we are also questioning labels and definitions. Is gender history a field, in the same sense that we talk about social history, political history, or even Canadian history? Does it encompass a substantial body of literature that is reasonably coherent and shares enough characteristics to be called a "field"? Or is it not yet a field in this sense because it is relatively new, encompasses a widely disparate literature, and sometimes can be used ahistorically? Perhaps it may be more useful at this point to view gender history as an approach/epistemology rather than as a field in direct competition with women's history. Whether one finds gender history approaches useful is another question, one that has been answered in the affirmative by a number of Canadian historians researching women and gender topics. No doubt Sangster is correct in pointing out that some writers assume that gender history first provided a critical understanding of "femininity" and later, "masculinity." Clearly, this is not an accurate reflection of developments in the historiography. Indeed, a major figure in the field, Joy Parr, says that "gender history made masculinity and femininity commensurably problematical historically, while insisting that neither could be well understood without companion inquiries into the other hierarchies with which they were mutually intertwined." 13 There are some fundamental problems, we agree, with what appears as a rather Whiggish approach - women's history also problematized femininity and some of the early social history also began to raise questions about masculinity. But, fundamentally, there seems to be a difference between the emphases in the two approaches - much more weight 
is placed on identities constructed in relationship to each other in gender history, thus making agency more difficult to get at. And this is one of the key problems with the gender history approach - how to understand the "whys" and the "whos" rather than the "hows."

Gender history is also a term that has been used variously in the past. In the older sense of that term, we understand a history that includes men and an analysis of gender relations; indeed, twenty years ago French historian, Natalie Davis, was calling for this kind of history in her path-breaking piece in Feminist Studies. Much like Joan Kelly in her work on the Renaissance, Davis noted the importance of studying the sexes in relation to one another. ${ }^{14}$ In more recent Canadian women's history, writers interested in ethnic women's history have also made it a point to include men and to analyze gender relations. These authors (Frager and Iacovetta, to name two) have, as yet, not really practiced "gender history" in its most recent incarnations. Currently, gender history refers to a number of perspectives and practices; at heart, however, its proponents tend to stress the social construction of identities, the multiplicities of meanings, and the formation of experience through discourses, that is, "discourses are the medium through which experiences are comprehensible." 15 In this view, experiences are shaped through language which is key in helping to make sense of, or give meaning to, events. Gender history proponents insist that by making categories like "experience" problematic, we are able to dissect the elements involved and thus to get at how power works through various discourses that set limits, draw boundaries and make hierarchies seem "natural."

14 Natalie Zemon Davis, "Women's History in Transition: The European Case," Feminist Studies, 3, 4 (Winter 1975); Joan Kelly, Women, History and Theory (Chicago 1984).

15 Parr, "Gender History and Historical Practice," 365. 


\section{Masculinity}

One of the subjects much discussed by those pursuing gender history is masculinity. As noted by many scholars, recognition of masculinity as a social construct preceded its current incarnation within gender history. As historians began to analyze how "femininity" was culturally and socially "naturalized", some applied these insights to men and male gendered identities. While "masculinity" is very much "in the air" these days, and as Sangster observes, a growing subject of interest at conferences, the body of historical work actually available on Canada remains as yet too small to permit conclusions about the primary preoccupations or politics of its practitioners.

Internationally, the last few years have seen a burst of activity on this front, including research on working-class and middle-class occupations, ritual and fraternalism, fatherhood and homosexuality. Various approaches have been adopted. As Michael Roper and John Tosh observe, some historians exploring male identities, including feminist labour historians and gay historians, have been attuned to questions of men's power, especially in relation to the "other", whether that be women, gay men or racial-ethnic minorities. ${ }^{16}$ Gay history has been important for excavating the sites and privileges of heterosexual power, alerting us to divergent views of sexual/gender identity, and raising questions about what constituted homosexual practice and identity. With few exceptions, ${ }^{17}$

16 For examples see: Michael Roper and John Tosh, ed., Manful Assertions: Masculinities in Britain Since 1800 (London and New York 1991); the essays in Ava Baron, ed., Work Engendered: Toward a New History of American Labor History (Ithaca, NY 1991); and Anne-Louise Shapiro, ed., Feminists Revision History (New Brunswick, NJ 1994); George Chauncey, Gay New York: Gender, Urban Culture and the Making of the Gay Male World, 1890-1940 (New York 1994); John d'Emilio and Estelle Freedman, Intimate Matters, a History of Sexuality in America (New York 1988).

17 For example, Leonore Davidoff and Catherine Hall, Family Fortunes: Men and Women of the Middle Class, 1790-1850 (Chicago 1987). 
scholars of middle-class men so far have shown less engagement with questions of male power and have paid less attention to relevant feminist insights. ${ }^{18}$ Interestingly, historians of masculinity who have drawn on feminist scholarship, such as Roper and Tosh, have pointed to the political and subversive potential of such studies where they expose patriarchal, heterosexual, racial, and class privilege. It remains to be seen, of course, whether such concerns will reflect a minority or majority position among the growing numbers of scholars taking up the subject. ${ }^{19}$

A small and diverse group of Canadian historians, most of them not post-structuralists, have produced only a smattering of articles dealing with male identity or manliness. In as much as this tiny literature can withstand historiographical dissection, there are a few trends worth noting. As Veronica Strong-Boag recently noted, the small number of Canadian studies that have taken masculinity seriously have dealt largely with marginalized groups, such as workers, gays and racialized Canadians. ${ }^{20}$ So far, questions related to masculinity have been more frequently taken up by workingclass historians, whether specialists on skilled Anglo-Celtic workers, family economies, domestic households or immigrants. Well before the rise of post-structuralism, labour historians interested in male workers' cultural and workplace traditions commented on the association of certain skills and/or dangerous jobs with heterosexual masculinity. ${ }^{21}$ Bradbury's 1987 article on women's history and working-class history helped hammer home the point that men were gendered not only at work but also at home and within the

18 For example, J.A. Mangan and James Walvin eds., Manliness and Morality: Middle-Class Masculinity in Britain and America (Manchester 1987)

19 Roper and Tosh, "Introduction, Manful Assertions; John Tosh, "What Should Historians Do With Masculinity? Reflections on Nineteenth Century Britain," History Workshop Journal (Autumn 1994).

20 Veronica Strong-Boag, Summary Comments, Masculinity panel, "Male Identities and the Working Class in Canada and Britain since 1870," ICHS, Montreal (August 1995).

21 See for example, Craig Heron, Working in Steel: The Early Years in Canada, 1883-1935 (Toronto 1988); Ian Radforth, Bushworkers and Bosses: Logging in Northern Ontario, 1900-1980 (Toronto 1987). 
family and community. ${ }^{22}$ These and other issues were later addressed by post-structuralist influenced labour histories that, while not eschewing a materialist framework, were especially keen to delineate the multiple gender identities of working men or pose questions about homosexual practice and sexual identity. ${ }^{23}$

Although still an emerging field in Canada, studies of sexuality, particularly gay history, represent probably the only other recognizable body of Canadian works addressing masculinity themes. Apart from an early attempt at a synthetic overview, ${ }^{24}$ so far we have a short list of essays exploring topics such as state repression of homosexuals, criminal prosecutions and the social histories of gay men who carved our sexual lives in defiance of normative and coercive powers of heterosexuality. ${ }^{25}$

The few other studies dealing with masculinity have been written from various perspectives and deal with a number of topics. These include: the fraternalism and/or outlook of middle-class professionals and businessmen; discourse analyses of colonial politics and religion; social history of sports; and feminist analyses of male violence. ${ }^{26}$ Given our knowledge of forthcoming publica-

22 Bettina Bradbury, "Women's History and Working Class History," Labour/Le Travail, 19 (Spring 1987), 23-43.

23 See for example, Rosenfeld, "It Was A Hard Life"; Parr, Gender of Breadwinners; Steve Maynard, "Rough Work and Rugged Men: The Social Construction of Masculinity in Working-Class History," Labour/Le Travail 23 (Spring 1989), 159-69; Christina Burr, "“That Coming Curse - The Incompetent Compositress': Class and Gender Relations in the Toronto Typographical Union during the Nineteenth Century," CHR, LXXIV, 3 (Sept. 1993) 233-66.

24 Gary Kinsman, The Regulation of Desire: Sexuality in Canada (Montreal 1987).

25 See, for example, Daniel J. Robinson and David Kimmel, "The Queer Career of Homosexual Security Vetting in Cold War Canada," CHR LXXV, 3 (September 1994), 319-45 and Steven Maynard, "Frivolous Boys' and 'Fallen Men': Danger and Desire in the Homosexual World of Working-Class Male Youth, Urban Ontario, 1890-1930," paper presented at masculinity panel, ICHS, Montreal, (August 1995). There are, of course, other publications in the works - these are but two samples.

26 Richard A. Willie, “"A Proper Ideal During Action': Fraternity, Leadership and Lifestyle in Winnipeg Lawyers' Professional Culture, 1878-1900," Journal of Canadian Studies, 27 (1992), 58-72; David G. Burley, A 
tions, conference proposals, and doctoral dissertations in the making, we would venture to say that this diversity of topics and approaches is bound to continue into the near future. We would therefore suggest that it is premature to categorize Canadian masculinity studies as accentuating the "positive" aspects of men's lives.(see Sangster, 117-8) Much of the work to date has consisted of social histories seeking to recover the dignity of marginalized men targeted by class-based, racist, and heterosexist scorn. But like Sangster, we urge the writing of historical studies that expose and explain the abuses of male power, and the persistent damage done to women, children and minorities (sexual and otherwise) in the name of marriage and family values. Not surprisingly, most of the interest shown in the gendered identities of the marginalized has come from social historians; however, more feminist-inspired gendered political histories of nation-making, statesmanship and nationalist narratives are also much needed.

\section{Race/Ethnicity}

Like Sangster, we welcome the increasing attention paid to race/ethnicity in both women's and gender history, although clearly much more work needs to be done. Moreover, we would argue that the challenges raised by feminist, leftist and other scholars of race studies, and the potentially transformative impact such challenges might have on the writing of history is far more complex than Sangster suggests.

While attention to race/ethnicity might be readily accommodated within a gender history approach that addresses the multiple

Particular Condition of Life: Self-Employment and Social Mobility in Mid-Victorian Brantford, Ontario (Montreal 1994); Cecilia Morgan, Public Men and Virtuous Women: The Gendered Languages of Religion and Politics in Upper Canada, 1791-1850 (Toronto forthcoming); Colin Howell, Northern Sandlots: A Social History of Maritime Baseball (Toronto 1995) and Dubinsky, Improper Advances. 
and fractured nature of identities, it would be misleading to suggest that race as a category of analysis has emerged only within poststructuralist and gender history contexts. Indeed, some scholars have recently pointed to the artificiality of race as a construct since categorizations of race have little to do with science and more to do with culture. The "challenge of race" has come from many directions, perhaps most strongly from feminists of colour writing minority women's history, from left feminist academics of diverse racial/ethnic backgrounds, and from minority feminists within the women's movement. Such calls for rigorous race analyses cannot be entirely met by the presence of studies that consider the histories of immigrant and minority women in the Canadian past. Even the familiar response of pointing to one or two early studies of the fur trade (Van Kirk's Many Tender Ties or Brown's Strangers in Blood) does not really make up for the lack of historical research on topics such as native women's history. ${ }^{27} \mathrm{~A}$ few books cannot stand in for an entire field or make up for the unwritten histories of groups rendered as "others." As Van Kirk and others grappling with these questions have commented, discussions about "otherness," "whiteness" and the subject positions of writers can provoke us to re-examine the history of native-white and other race relations. ${ }^{28}$

Moreover, the "challenge of race" has been simultaneously a series of intellectual and political challenges that demand a great deal more from all of us than some acknowledgement that race/ethnicity is a factor (among many) influencing identity formation. These debates prod us to think about race/ethnicity and racism as systems of power and oppression. They provoke us to try to understand how historical events, processes and institutions are profoundly racialized phenomena. Just as gender is a pertinent

27 Sylvia Van Kirk, Many Tender Ties: Women in Fur Trade Society, 1670-1870 (Winnipeg 1980); Jennifer Brown, Strangers in Blood: Fur Trade Company Families in Indian Country (Vancouver 1980).

28 See for example, Vron Ware, Beyond the Pale: White Women, Racism, History (London 1992); David Roediger, The Wages of Whiteness: Race and the Making of the American Working Class (London 1991). In conversation with Sylvia Van Kirk. 
category of analysis even when women are not the subject, so too are race and ethnicity relevant even when we are writing about Euro-Canadians.

\section{Will Women's History Disappear?}

Will women's history disappear, left behind in the dust as future historians adopt perspectives friendlier to gender history? Our opinion is that women's history is in no such danger, judging from our numerous and active colleagues and students. Because women's history is recognized as a "field" while gender history as yet approximates a set of approaches or possible frameworks, we see them as complementary, if not in an easy relationship. Indeed, neither one is monolithic; there are many varieties of both women's history and gender history. Both must be criticized for not paying attention to class, race, ethnicity, if need be, and the way they use gender as a category of analysis remains open to interrogation. Thus, we would urge readers to remember that women's history practitioners are not all the same, just as gender history covers a wide territory that is not just deconstruction à la Joan Scott. We look forward to and encourage feminist input into all subjects open to historical research. And if male colleagues find "gender history" more welcoming as a label (which appears to be the case), then perhaps we will see more men addressing the sorts of issues we have raised in this brief comment on Sangster's piece. It is our hope that we can continue to criticize and comment on each other's approaches, use of evidence and categories of analysis. Whether we think of ourselves as women's historians or gender historians, it is important to realize the limitations of such labels. Labels do not free us of the obligation to interrogate each other's methods and approaches, nor do they dictate what topics are legitimate (or illegitimate). 


\section{Conclusion}

As historians, our craft does not stand still; as socialists and feminists, our politics and strategies constantly undergo reflection and critique. Over the decades the writing of women's history has also experienced change and no doubt the writing of gender history will also undergo changes and develop new facets. Rather than prioritizing one or another type of specialization or approach, it seems to make sense to argue for feminist analysis, broadly defined, in all areas of research and in all approaches to research and writing. Moreover, women's history and the communities of women's historians across the country can offer critical political, intellectual, and personal support to colleagues and students who work in fields other than women's history, in male-dominated fields, and in fields that have barely begun to recognize the challenges posed by feminist history. This is particularly important in the current political climate where divisions make us more vulnerable to right-wing and anti-feminist backlashes, not only within the academy but in society more generally. At a time of ever-tightening labour markets and right-wing government agendas, it seems particularly important for us to support colleagues and students at the very least by engaging in debate and, one hopes, by building our networks. We are well aware that these kinds of debates in history are occurring elsewhere, perhaps most viciously in the British journal, Social History where at least one prominent historian of the British working class has all but repudiated Marxism, materialism, and the concept of class itself to replace it with "post-modernist" thought. ${ }^{29}$ We have higher hopes for feminist history. One of our main concerns in this piece has been to bring some of the issues forward in ways that move beyond the polemical remarks made in

29 In particular, see Patrick Joyce, "The End of Social History?" Social History, 20, 1 (Jan. 1995) and GeoffEley and Keith Nield, "Starting Over: the present, the post-modern and the moment of social history," Social History, 20, 3 (Oct. 1995). 
"Beyond Dichotomies." As noted at the beginning of this piece, polemics have both good and bad aspects; we hope that readers will take up the issues raised. 